\title{
Recruitment habitats and nursery grounds of the American lobster Homarus americanus: a demographic bottleneck?
}

\author{
Richard A. Wahle ${ }^{1^{*}}$, Robert S. Steneck ${ }^{2}$ \\ ${ }^{1}$ Department of Zoology, University of Maine, and Darling Marine Center, Walpole, Maine 04573, USA \\ ${ }^{2}$ Department of Botany and Plant Pathology, Department of Oceanography, University of Maine, and Darling Marine Center, \\ Walpole, Maine 04573, USA
}

\begin{abstract}
We have identified benthic recruitment habitats and nursery grounds of the American lobster Homarus americanus Milne Edwards in the coastal Gulf of Maine, USA, by systematically censusing subtidal sediment, cobble, and ledge substrata. We distinguish lobsters between settlement size (5 mm carapace length (CL)) to ca $40 \mathrm{~mm}$ CL as the 'early benthic phase' (EBP) because they are ecologically and behaviorally distinct from larger lobsters. EBP lobsters are cryptic and apparently restricted to shelter-providing habitats (primarily cobble substratum) in coastal Gulf of Maine. In these habitats we found average population densities of EBP lobsters as high as $6.9 \mathrm{~m}^{-2}$ EBP lobsters were virtually absent from ledge and sedimentary substrata devoid of vegetation although larger lobsters are commonly found there. It is possible that the requirement for shelter-providing substrata by this life phase creates a natural demographic 'bottleneck' to benthic recruitment for the species. Prime cobble recruitment habitat is relatively rare and comprises ca $11 \%$ of the $60.2 \mathrm{~km}$ of shoreline at our study area in midcoast Maine. If this low availability of cobble exists throughout the Gulf of Maine, as other studies indicate, it could limit lobster production potential. We verified the geographic extent of recruitment to cobble habitats censused in 3 of 4 regions spanning ca $300 \mathrm{~km}$ of the coastal Gulf of Maine (from Nahant, Massachusetts to Swans Island, Maine). Early benthic phase lobsters were absent from cobble censused in the northeastern extreme of our survey (Swans Island). This pattern is consistent with earlier speculation that relatively cool water temperatures may limit larval settlement in this region.
\end{abstract}

\section{INTRODUCTION}

American lobster Homarus americanus Milne Edwards populations are dependent on settlement of pelagic larvae to coastal locations (Phillips \& Sastry 1980, Cobb et al. 1983, Fogarty 1983, Hudon et al. 1986, Harding \& Trites 1988), but the benthic habitats to which they recruit and where they spend early life remain largely unknown (Caddy 1986, Cobb 1986). Most workers have suspected that lobster populations are limited by larval supply (e.g. Wilder 1953, Scarratt 1973, Harding et al. 1982, and see review in Cobb \& Wang 1985). For example, in one of the few regions having data available to study such questions, Scarratt (1973) and Harding et al. (1982) found a linear relation-

\footnotetext{
- Present address: Program in Ecology and Evolutionary Biology, Box G-W, Brown University, Providence, Rhode Island 02912, USA
}

ship between larval abundance and subsequent harvests. But a re-analysis of the same data set by Fogarty \& Idoine (1986) suggested that year-to-year fluctuations in larval supply are not reflected in subsequent recruitment to adult populations. These authors proposed that the population was limited by the availability of suitable benthic habitat and may be subject to density-dependent controls. This would suggest that lobsters suffer a critical period of mortality, a demographic 'bottleneck', at or soon after benthic recruitment, that largely determines the size of adult populations (Caddy 1986, Conan 1986). In either case, the role habitat may play in fundamentally limiting lobster populations is unknown. Moreover, little is known of the quality or extent of habitats in which the earliest benthic lobsters are found.

Bottlenecks to recruitment are known to occur in a variety of organisms dependent on habitat refugia early in life (e.g. Werner \& Gilliam 1984, Steger 1987. 
Quinn \& Janssen 1989). Shelter is suspected to be the specific limiting resource for lobsters in benthic habitats (Caddy 1986, Fogarty \& Idoine 1986). Indeed, many benthic crustaceans with small bodies and exposed abdomens in shallow marine and aquatic environments are shelter-dependent (e.g. hermit crabs: Vance 1972, Bertness 1981; stomatopods: Steger 1987. Moran \& Reaka 1988; crayfish: Stein \& Magnuson 1976; and spiny lobsters: Marx \& Herrnkind 1985, Howard 1988, Spanier \& Zimmer-Faust 1988, Yoshimura \& Yamakawa 1988). Among these crustaceans, shelter occupancy reduces the risks of predation (e.g. Stein \& Magnuson 1976), physical disturbance (e.g. Howard 1980, Howard \& Nunny 1983), and/or physiological stress (e.g. Bertness 1981). Moreover, strong, ritualized competition for shelter is well known in many of these groups, suggesting shelter-limitation has played an important part in their evolutionary history. Thus, the sizes and numbers of shelters may place limits on the sizes and numbers of their occupants, but there are no quantitative descriptions of the sheltering quality of American lobster habitat.

Although habitat selection studies in the laboratory have been helpful in identifying potential lobster recruitment habitats, their implications for lobster demography are ambiguous. For example, settling Homarus species are known to seek the shelter of rocks and vegetation (Cobb 1968, Botero \& Atema 1982, Pottle \& Elner 1982, Cobb et al. 1983, Johns \& Mann 1987), but they are also adept burrowers in featureless mud $(H$. americanus: Berrill \& Stewart 1973, Botero \& Atema 1982, Cobb et al. 1983; H. gammarus: Howard \& Bennett 1979). Recent video-monitored predation experiments in the field (Wahle 1988, 1990) confirm the importance of predators and the vulnerability of small unsheltered lobsters previously only demonstrated under relatively artificial conditions of the laboratory or field enclosures (Roach 1983, Richards \& Cobb 1986, Lavalli \& Barshaw 1986, Johns \& Mann 1987, Barshaw $\&$ Lavalli 1988). While these studies have enabled valuable inferences to be made as to the kinds of habitats in which the American lobster may settle, there have been few quantitative descriptions of newly recruited lobsters in nature (Hudon 1987, Able et al. 1988) and none from the Gulf of Maine.

Recent field studies of newly recruited lobsters in the Gulf of St. Lawrence (Hudon 1987) have provided information on growth and population densities, but only a qualitative description of the rather heterogeneous habitat to which they recruit. Clearly, it is necessary to quantify habitat-specific patterns of abundance of newly recruited lobsters before meaningful hypotheses can be advanced about the processes influencing their distribution and abundance.

This study describes the distribution and abundance of 'early benthic phase' (EBP) lobsters and the habitats in which they are found within several months of benthic recruitment at subtidal coastal sites in the Gulf of Maine, USA. By proposing the phrase, 'EBP', we distinguish an ecological life phase that does not correspond with a morphologically distinct developmental stage. This research shows that EBP lobsters form a demographically distinct segment of lobster life history that is strongly associated with a relatively limited shallow water cobble habitat. These findings are consistent with previous assertions that benthic recruitment may be limited by habitat availability. We quantitatively describe this habitat relative to potential shelter availability. Finally, we give evidence of dramatically lower recruitment in the northeast extreme of the $300 \mathrm{~km}$ segment of coast we censused and propose why this may be so

\section{STUDY ORGANISM, STUDY SITES, AND GENERAL METHODS}

Benthic phases of lobster life history. We feel it is important to clarify our use of the name 'early benthic phase', because similar, but confusing, terminology exists in the literature. Below, we propose names for 3 benthic life phases of the American lobster we have recognized in practice and in the literature: early benthic phase (EBP), adolescent phase (AP), and reproductive phase (RP). EBP refers to lobsters from settlement (ca $5 \mathrm{~mm} \mathrm{CL}$ ) to between 20 and $40 \mathrm{~mm} \mathrm{CL}$ that tend to be the most cryptic segment of the life history. The wide upper limit of the EBP reflects local and perhaps individual differences in the use of shelterproviding habitats (Hudon 1987, Cobb pers comm., Wahle pers. obs.). Therefore, in this study we operationally refer to lobsters from 5 to $40 \mathrm{~mm}$ CL as EBP. In the discussion, we further defend why we think EBP is a more appropriate term than others proposed for this earliest part of benthic life.

We call the larger, more conspicuous pre-reproductive lobsters the adolescent phase (AP). This life phase dominates nearshore (Campbell \& Pezzack 1986), where it forages nocturnally (Stewart 1972, Lawton 1987), and usually exhibits annual movements of a few km (Cooper et al. 1975, Krouse 1980, 1981, Munro \& Therriault 1983, Ennis 1984, Campbell \& Stasko 1985, 1986). The size at onset of the reproductive phase (RP) is temperature-dependent (Aiken \& Waddy 1980). Female maturity occurs at $65 \mathrm{~mm}$ CL south of Cape Cod, Massachusetts and $110 \mathrm{~mm}$ CL in the colder Bay of Fundy. From this time on, RP lobsters are even more mobile and tend to diffuse from shallow, coastal habitats toward deeper coastal or offshore waters (Cooper \& Uzmann 1971, Uzmann et al. 1977. Camp- 
bell \& Stasko 1985, 1986, Campbell 1986, Pezzack \& Duggan 1986).

Identifying recruitment habitats.

Study sites: To determine recruitment habitats of EBP lobsters, 5 sampling sites were examined along a gradient from estuarine to outer coast environments in the Pemaquid area of mid-coast Maine $(13 \mathrm{~km}$ distance; Fig. 1). These sites span a range of subtidal coastal habitats common to the central Gulf of Maine. Pemaquid Harbor ( $\mathrm{PH})$ is a shallow $(<7 \mathrm{~m}$ depth) protected estuary with patches of mud-sand, eelgrass, and cobble adjacent to each other. Rutherford Island (RI) is a semiprotected site having sand-mud, cobble, and ledge substrata to $20 \mathrm{~m}$ depth. Unlike the other 4 locations, rock surfaces at RI are covered with a dense kelp (Laminaria spp.) canopy extending below $10 \mathrm{~m}$ depth. Pemaquid Point (PP), Ocean Point (OP), and Damariscove Island (DI) are exposed sites with extensive bedrock slopes with patches of cobble and sand ranging from a few to $>100 \mathrm{~m}$ in breadth. Rock surfaces below ca 2 to $3 \mathrm{~m}$ at these last 3 sites are denuded of macroalgae by the sea urchin Strongylocentrotus droebachiensis. Surface temperatures in the estuaries vary seasonally from $-1{ }^{\circ} \mathrm{C}$ to about $18^{\circ} \mathrm{C}$ and on the outer coast from ca 2 to $16^{\circ} \mathrm{C}$.

Sampling techniques: Lobster postlarvae settle in mid-coast Maine from early August to early September. Settlement is a few weeks earlier to the south and a few weeks later to the north. Censuses were conducted in June, July, and the first week of August in 1987 and 1988. Therefore, the vast majority of the lobsters we censused had recruited the previous year and earlier.

Sampling was stratified by depth and primary substratum. Collections were made at 5 and $10 \mathrm{~m}$ below mean low water except at $\mathrm{PH}$ where only the $5 \mathrm{~m}$ depth was available. These depths were chosen because larvae are dispersed in the neuston (Phillips \& Sastry 1980, Cobb et al. 1983) and behavioral evidence indicates that postlarvae make shallow dives to test bottom (Cobb 1968, Ennis 1975, Cobb et al. 1983, Cobb et al. 1989.

We attempted an even sampling of the spectrum of primary substrata available at a given site regardless of what biota covered it. Primary substrata fell into 3 broad categories: (1) sediment (mud or sand), (2) ledge (bedrock), and (3) cobble, which is a heterogeneous mixture of pebbles, cobbles, and boulders as defined by Wentworth (1922, in Shepherd 1964). These 3 substratum categories constitute the vast majority of primary substrata available subtidally and were sampled at all sites except at $O P$ where no sediment substratum could be found shallower than $10 \mathrm{~m}$, and at $\mathrm{PH}$ where there was no bedrock. At PH we sampled sediment substratum inside and outside eelgrass beds. At the

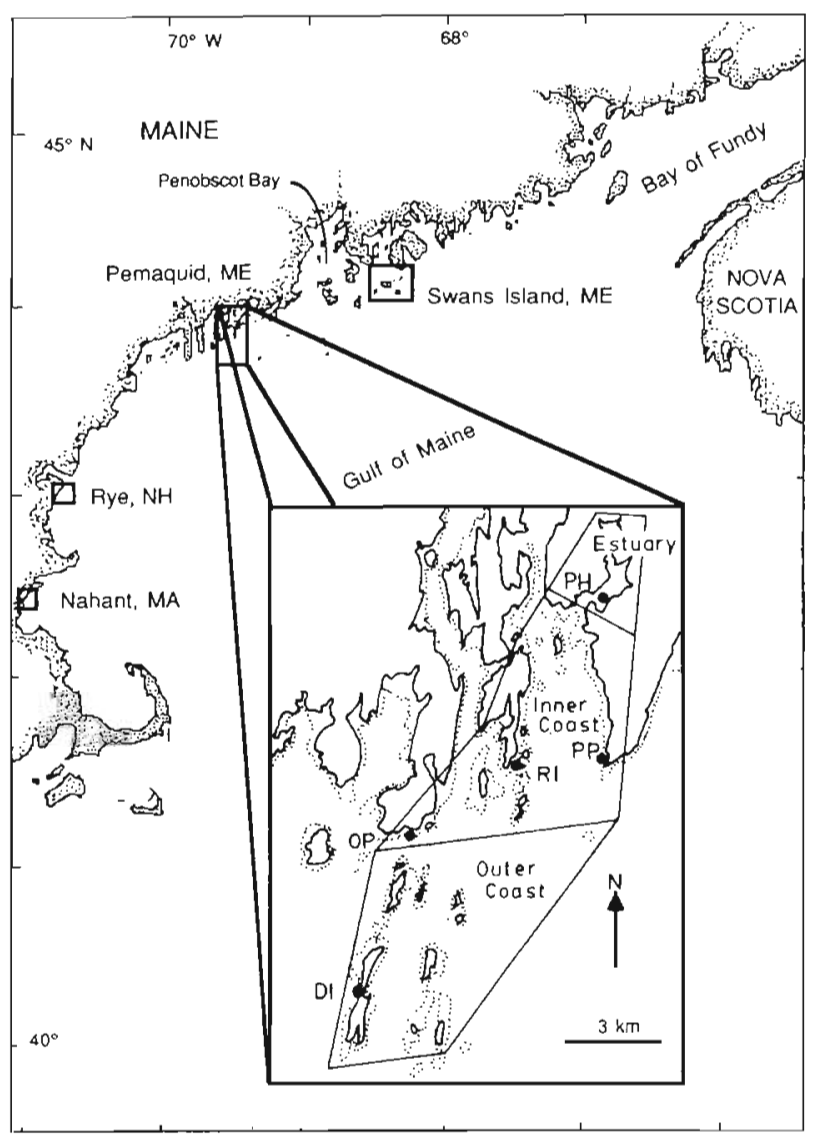

Fig. 1. Study areas in the Gulf of Maine and detail of study sites at the Pemaquid, Maine, USA, study area (inset). $\mathrm{PH}=$ Pemaquid Harbor, RI = Rutherford Island, $\mathrm{PP}=$ Pemaquid Point, $\mathrm{OP}=$ Ocean Point, $\mathrm{DI}=$ Damariscove Island. Dotted line in inset shows the $10 \mathrm{~m}$ isobath

other sites it was not possible to make similar comparisons of vegetated or mussel-dominated rock with uncolonized rock; therefore we did not attempt a comprehensive survey of habitats dominated by macroalgae or mussels.

At each site and depth, $0.25 \mathrm{~m}^{2}$ quadrats were haphazardly and blindly tossed on the substratum by the diver at least $2 \mathrm{~m}$ apart. We considered haphazard sampling to be a reasonable compromise of the more desirable random sampling technique because patches of cobble substratum we encountered varied from about a meter to tens of meters in breadth. In the cobble habitats, rarely was the quadrat thrown on boulders too heavy to move. If it was impossible to sample under the boulder the quadrat was tossed again. All lobsters found were measured ( $\mathrm{mm} \mathrm{CL}$ ) and shelter-use was recorded. To minimize lobsters escaping our detection, extreme care was taken by working slowly to maintain visibility. We learned that if we moved the substratum slowly lobsters would more likely emerge 
into sight in a claw display rather than tailflipping, making them easy to capture.

Where visibility was very good (e.g. urchin-grazed ledge and coarse sand), divers could census the bottom without the use of a sampling device. However where visibility was limited when the substratum was disturbed (usually due to silt), samples were taken using an airlift suction sampler. With the airlift, silt was conducted away, maintaining visibility in the immediate work area. The airlift is a $120 \mathrm{~cm}$ length of $7.6 \mathrm{~cm}(3$ inch) diameter PVC tube with a SCUBA tank air supply entering a few $\mathrm{cm}$ above the mouth of the tube. It is equipped with $1.0 \mathrm{~mm}$ nylon mesh collection bags which can be changed underwater for successive quadrats.

Censusing a quadrat with an airlift involved 2 divers, one operating the airlift while the other carefully dismantled rocks individually. Rocks were removed until there were no more interstitial spaces to expose. In some cobble beds we excavated 30 to $40 \mathrm{~cm}$ into the substratum. Mud substrata were suction-sampled to a depth of at least $15 \mathrm{~cm}$, since the U-shaped tubes of lobsters observed in the laboratory (Berrill \& Stewart. 1973, pers. obs.) were less than this depth. Large vegetation (e.g. eelgrass or kelp) was cut short to facilitate the airlift process, and kelp holdfasts were dislodged under the airlift to capture interstitial organisms. The advantages of this technique over the manual census technique described by Bernstein \& Campbell (1983) and Hudon (1987) are that one is not as constrained by low visibility to catch lobsters, and it is much less laborious to obtain replicate samples. The disadvantage is that we cannot provide estimates of sampling efficiency. Nevertheless, this study reports some of the highest EBP densities on record and the possibility of higher population densities only amplifies our conclusions.

The necessary sample size was determined by plotting quadrat number against the cumulative mean and variance of lobster density from the 1987 collections at DI. We determined that the mean and variance stabilized at ca 10 quadrats. Therefore, in 1988 we chose to sample 16 quadrats as a conservative minimum sample size at each site. In 1987 (3 June to 4 August) samples were taken from all 3 substratum categories (where available) (Table 1a). In 1988 (10 June to 16 July) sampling was repeated at the same 5 sites, but only on cobble bottom to assess annual population variability.

During the 1988 census the quadrats within cobble habitats at the $5 \mathrm{~m}$ depth were photographed for substratum analysis (below). The quadrats were cleared of

Table 1a. Homarus americanus. Lobster population density (individuals $\leq 40 \mathrm{~mm} \mathrm{CL}$ ) by substratum, depth, and year, at each site in the Pemaquid, Maine, study area including characteristic vegetational states. Data presented as mean number of individuals $\mathrm{m}^{-2}, \pm S D$, and (no. quadrats). Site abbreviations as in Fig. 1. Dashes: absence of habitats with given characteristics

\begin{tabular}{|c|c|c|c|c|c|c|c|c|c|}
\hline \multirow{3}{*}{ Site } & \multirow{3}{*}{$\begin{array}{l}\text { Vegetat. } \\
\text { state }\end{array}$} & \multicolumn{4}{|c|}{$5 \mathrm{~m}$} & \multicolumn{4}{|c|}{$10 \mathrm{~m}$} \\
\hline & & \multirow[t]{2}{*}{ Sediment } & \multicolumn{2}{|c|}{ Cobble } & \multirow[t]{2}{*}{ Ledge } & \multirow[t]{2}{*}{ Sediment } & \multicolumn{2}{|c|}{ Cobble } & \multirow[t]{2}{*}{ Ledge } \\
\hline & & & 1987 & 1988 & & & 1987 & 1988 & \\
\hline DI & Unveg. & $\begin{array}{r}0.0 \\
\pm 0.0 \\
(24)\end{array}$ & $\begin{array}{r}6.1 \\
\pm 5.0 \\
(23)\end{array}$ & $\begin{array}{r}6.9 \\
+5.5 \\
(15)\end{array}$ & $\begin{array}{r}0.2 \\
\pm(0.8) \\
(24)\end{array}$ & $\begin{array}{r}0.0 \\
\pm 0.0 \\
(24)\end{array}$ & $\begin{array}{r}2.3 \\
\pm 2.8 \\
(24)\end{array}$ & $\begin{array}{r}3.0 \\
\pm 3.1 \\
(16)\end{array}$ & $\begin{array}{r}0.2 \\
\pm 0.8 \\
(23)\end{array}$ \\
\hline OP & Unveg. & - & $\begin{array}{r}3.4 \\
\pm 4.0 \\
(20)\end{array}$ & $\begin{array}{r}3.0 \\
+3.4 \\
(16)\end{array}$ & $\begin{array}{r}0.0 \\
\pm 0.0 \\
(24)\end{array}$ & - & $\begin{array}{r}1.6 \\
\pm 2.6 \\
(23)\end{array}$ & $\begin{array}{r}6.7 \\
\pm 4.5 \\
(16)\end{array}$ & $\begin{array}{r}0.0 \\
\pm 0.0 \\
(23)\end{array}$ \\
\hline PP & Unveg. & $\begin{array}{r}0.0 \\
\pm 0.0 \\
(30)\end{array}$ & $\begin{array}{r}0.1 \\
\pm 0.7 \\
(31)\end{array}$ & $\begin{array}{r}1.5 \\
-2.9 \\
(16)\end{array}$ & $\begin{array}{r}0.0 \\
\pm 0.0 \\
(30)\end{array}$ & $\begin{array}{r}0.0 \\
0.0 \\
(31)\end{array}$ & $\begin{array}{r}0.7 \\
\pm 1.6 \\
(23)\end{array}$ & $\begin{array}{r}1.5 \\
\pm 2.0 \\
(16)\end{array}$ & $\begin{array}{r}0.0 \\
\pm 0.0 \\
(31)\end{array}$ \\
\hline $\mathrm{RI}$ & Unveg. & $\begin{array}{r}0.0 \\
\pm 0.0 \\
(19)\end{array}$ & - & - & - & $\begin{array}{r}0.0 \\
\pm 0.0 \\
(20)\end{array}$ & - & - & - \\
\hline & Laminaria & - & $\begin{array}{r}1.1 \\
+2.3 \\
(18)\end{array}$ & $\begin{array}{r}2.8 \\
+2.9 \\
(16)\end{array}$ & $\begin{array}{r}1.0 \\
+1.8 \\
\{20\}\end{array}$ & - & $\begin{array}{r}1.0 \\
\pm 2.2 \\
(20)\end{array}$ & $\begin{array}{r}1.0 \\
\pm 1.8 \\
(16)\end{array}$ & $\begin{array}{r}1.1 \\
+1.8 \\
(19)\end{array}$ \\
\hline $\mathrm{PH}$ & Unveg. & $\begin{array}{r}0.0 \\
\pm 0.0 \\
(20)\end{array}$ & $\begin{array}{r}3.8 \\
\pm 4.3 \\
(19)\end{array}$ & $\begin{array}{r}3.2 \\
\pm 2.6 \\
(16)\end{array}$ & - & - & - & - & - \\
\hline & Zostera & $\begin{array}{r}0.2 \\
\pm 0.8 \\
(23)\end{array}$ & - & - & - & - & - & - & - \\
\hline
\end{tabular}


Table 1b. Analysis of variance table for depth and year comparisons of EBP lobster population densities for 'cobble' sites in the Pemaquid, Maine, study area appearing in Table 1 a. Analyses are 2-factor ANOVAs except the analysis of $\mathrm{PH}$ which is a 1 -factor ANOVA. Values were $(x+1)$ transformed (Underwood 1981) before analysis

\begin{tabular}{|c|c|c|c|c|c|}
\hline Site & $\begin{array}{l}\text { Source of } \\
\text { variation }\end{array}$ & $\mathrm{df}$ & $\begin{array}{l}\text { Sum of } \\
\text { squares }\end{array}$ & $F$ & $p$ \\
\hline DI & $\begin{array}{l}\text { Depth } \\
\text { Year } \\
\text { Interaction } \\
\text { Error } \\
\quad \text { Total }\end{array}$ & $\begin{array}{r}1 \\
1 \\
1 \\
73 \\
76\end{array}$ & $\begin{array}{r}1.840 \\
0.075 \\
0.001 \\
8.669 \\
10.585\end{array}$ & $\begin{array}{r}15.50 \\
0.63 \\
0.01\end{array}$ & $\begin{array}{l}0.0002 \\
0.4298 \\
0.9262\end{array}$ \\
\hline OP & $\begin{array}{l}\text { Depth } \\
\text { Year } \\
\text { Interaction } \\
\text { Error } \\
\quad \text { Total }\end{array}$ & $\begin{array}{r}1 \\
1 \\
1 \\
71 \\
74\end{array}$ & $\begin{array}{l}0.131 \\
0.889 \\
0.995 \\
6.538 \\
8.553\end{array}$ & $\begin{array}{r}1.42 \\
9.65 \\
10.81\end{array}$ & $\begin{array}{l}0.2372 \\
0.0027 \\
0.0016\end{array}$ \\
\hline $\mathrm{PP}$ & $\begin{array}{l}\text { Depth } \\
\text { Year } \\
\text { Interaction } \\
\text { Error } \\
\quad \text { Total }\end{array}$ & $\begin{array}{r}1 \\
1 \\
1 \\
82 \\
85\end{array}$ & $\begin{array}{l}0.025 \\
0.226 \\
0.011 \\
2.463 \\
2.725\end{array}$ & $\begin{array}{l}0.83 \\
7.54 \\
0.36\end{array}$ & $\begin{array}{l}0.3651 \\
0.0074 \\
0.5498\end{array}$ \\
\hline RI & $\begin{array}{l}\text { Depth } \\
\text { Year } \\
\text { Interaction } \\
\text { Error } \\
\text { Total }\end{array}$ & $\begin{array}{r}1 \\
1 \\
1 \\
66 \\
69\end{array}$ & $\begin{array}{l}0.103 \\
0.087 \\
0.076 \\
3.331 \\
3.597\end{array}$ & $\begin{array}{l}2.04 \\
1.73 \\
1.50\end{array}$ & $\begin{array}{l}0.1574 \\
0.1927 \\
0.2243\end{array}$ \\
\hline $\mathrm{PH}$ & $\begin{array}{l}\text { Year } \\
\text { Error } \\
\text { Total }\end{array}$ & $\begin{array}{r}1 \\
33 \\
34\end{array}$ & $\begin{array}{l}0.004 \\
3.479 \\
3.483\end{array}$ & 0.04 & 0.8424 \\
\hline
\end{tabular}

macroalgae to expose the primary substratum before being photographed and sampled. These $0.25 \mathrm{~m}^{2}$ photoquadrats were taken using a Nikonos IV-A camera with a $15 \mathrm{~mm}$ lens and 2 Ikelite MS strobes mounted on a quadrapod.

To generate size-frequency distributions of lobsters on soft substratum where populations densities were very sparse, divers traversed $200 \mathrm{~m}$ rope transects perpendicular to the shore in 7 to $12 \mathrm{~m}$ depths at RI during June and July 1987 and 1988.

Quantifying benthic habitats: To map substratum types in the Pemaquid study area (Fig. 1) we surveyed $60.2 \mathrm{~km}$ of shoreline by boat. Shoreline distances were measured with dividers on a nautical chart to determine the proportion of coastline comprised by each substratum type. Observations made by diver, by remotely operated vehicle video camera, and from nautical charts confirmed that, usually, the substrata observed at the shoreline extends subtidally to at least $10 \mathrm{~m}$ depth, but sediment generally becomes the predominant substratum with greater depths. Of 35 sites examined, $27(77 \%)$ had the same substratum to $5 \mathrm{~m}$ depth. Only 2 of the 35 sites were shallower than $10 \mathrm{~m}$, so of the remaining 33 sites, $22(67 \%)$ had the same substratum type to at least $10 \mathrm{~m}$.

With depth, a transition from cobble to mud is common on protected shores, and from bedrock to boulders on high energy shores. Thus, it is possible we have overestimated cobble in the former, and underestimated it in the latter case. However, our surveys suggest that shoreline cobble giving way to another substratum subtidally is more likely to be found than the reverse. Of the 35 sites we inspected, 14 had cobble on shore, and at $10(71 \%)$ of these cobble sites, the cobble was continuous to $5 \mathrm{~m}$. In contrast, of the remaining 21 sites having ledge or sediment shores, only $1(5 \%)$ had cobble at $5 \mathrm{~m}$. At $10 \mathrm{~m}$ depth (33 sites), the pattern was similar but less strong; $5(38 \%)$ of the 13 sites with cobble on shore had cobble to $10 \mathrm{~m}$, whereas only 2 $(10 \%)$ of the 20 sites with ledge or sediment shores had cobble at $10 \mathrm{~m}$. Finally, because fine-grained sedimentary environments tend to slope gently, they tend to occupy a larger area within a depth zone (note estuary in Fig. 1) than cobble environments which tend to slope more steeply. Thus, there is perhaps more reason to believe that we overestimated than that we underestimated relative cobble cover.

Substratum size distribution and percent cover were estimated from photoquadrats within cobble habitats at the $5 \mathrm{~m}$ depth (above). Maximum and minimum diameters of randomly selected rocks were measured, as they appeared in the photographs, using a point-intercept technique with 50 points. Where more than one point fell on the same object, only one set of measurements was taken, but the number of points was counted in order to estimate the percent cover of each size category. An estimate of the size-frequency distribution of rocks was determined by multiplying the percent cover for a size class by the maximum number of rocks (assuming spheres) of that size that could fit in a square meter. If mussels were present they too were measured as a component of the cobble habitat.

Rock diameters are expressed in standard geological units of Phi [Phi $=-\log _{2}$ (mm diameter)] (e.g. Shepherd 1964). It is conventional to use the negative logarithm of particle diameter so that sediments, most of which are less than $1 \mathrm{~mm}$ in diameter, can be expressed in positive Phi units. But since particles that create lobster shelters are all much larger than $1 \mathrm{~mm}$, we used the positive logarithm of diameter.

Quadrat size limits the rock size that can be measured. Thus, as rock size increases, the proportion included in the quadrat decreases. For the $0.25 \mathrm{~m}^{2}$ quadrat, virtually all rocks with a maximum diameter $<7$ Phi (128 mm) were individually measured, but rocks greater than or equal to 7 Phi were treated as one size category ( $\geq 7$ Phi) because many fell outside the field of view. At the other extreme, the limit of resolu- 
tion at the distance photographed dictated that particles less than $4 \mathrm{~mm}$ (coarse sand) be categorized as $<2$ Phi.

Regional demography. To examine EBP populations on a wider geographic scale, we examined additional areas within the Gulf of Maine (Fig. 1). Along with Pemaquid these areas are spaced at approximately equal intervals along the coast. There were 11 sites in the vicinity of Swans Island near Mt. Desert Island, Maine, 1 site at Rye, New Hampshire, and 3 at Nahant, Massachusetts. The census sites were chosen on the basis of the shoreline substrata, navigational charts, and local knowledge. Sampling was mostly restricted to cobble bottom at 3 to $6 \mathrm{~m}$ depth. We chose outer coast, non-estuarine sites to place some control on the range of hydrographic conditions among locations. Average water temperatures at the surface and $10 \mathrm{~m}$ during the warmest months [August and September, as determined from a 20 yr mean by Colton \& Stoddard (1972)] at all our study areas are: Swans Island: surface, 11 to $12^{\circ} \mathrm{C}, 10 \mathrm{~m}, 11$ to $12^{\circ} \mathrm{C}$, Pemaquid: surface, 14 to $16^{\circ} \mathrm{C}$, $10 \mathrm{~m}, 13$ to $15^{\circ} \mathrm{C}$; Rye: surface, 15 to $17^{\circ} \mathrm{C}, 10 \mathrm{~m}, 14$ to $16^{\circ} \mathrm{C}$; Nahant: surface, 16 to $19^{\circ} \mathrm{C}, 10 \mathrm{~m}, 16$ to $17^{\circ} \mathrm{C}$.

\section{RESULTS}

\section{Recruitment habitats}

\section{Associations with primary substrata}

Lobsters of all sizes were concentrated in cobbleboulder habitat, but the association was strongest for EBP lobsters. Early benthic phase lobsters $(\leq 40 \mathrm{~mm}$ CL) were most abundant in cobble substratum, and were very rare on featureless soft or bedrock substrata where larger lobsters predominated (Fig. 2, Table 1a). The lobster population in cobble substratum had size modes of 11 and $18 \mathrm{~mm} \mathrm{CL}$ in 1987 and 1988 respectively (Fig. 2).

Unlike cobble habitats, we rarely found EBP lobsters in sedimentary (sand or mud) substrata (Fig. 2). Extensive airlift sampling for EBP lobsters at all sedimentary sites indicates that they were very rare as either epibenthos or infauna. The size distribution of lobsters on this substratum, measuring all lobsters along transects, had a mode of $58 \mathrm{~mm} \mathrm{CL}$ in both years

\section{Associations with biotic habitats}

Biotic habitats apparently influenced EBP population densities on hard substratum, but not on sediment or cobble substratum (Table 1a). Bedrock surfaces devoid of macroalgae and/or mussels harbored no EBP lob-

\section{COBBLE}

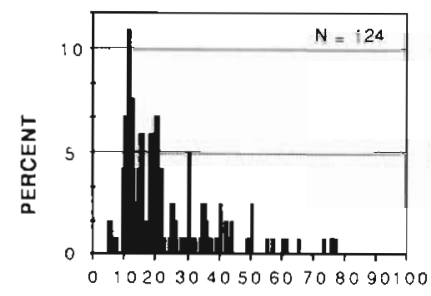

102030405060708090100

\section{SEDIMENT}

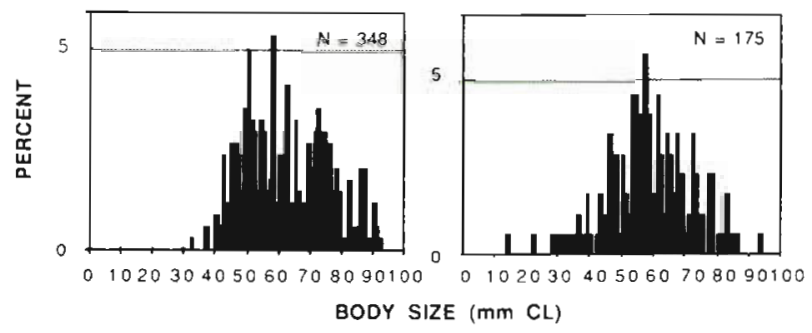

Fig. 2. Homarus americanus. Size-frequency distributions of lobsters found in cobble (from quadrat censuses, all sites pooled), and on featureless sediment substrata (from transects at RI) in 1987 and 1988 at the Pemaquid study area

sters. In contrast, the kelp - mussel (Laminaria spp. Mytilus edulis) colonized bedrock at RI had densities similar to those of adjacent cobble bottom at both 5 and $10 \mathrm{~m}$ (2-factor ANOVA (substratum $\times$ depth) of $、(x+1)$ transformed data (Underwood 1981); substratum effect: $F=0.001$, df $=1, p=0.960$; depth effect: $F=$ $0.004, \mathrm{df}=1, \mathrm{p}=0.952$; interaction $F=0.032, \mathrm{df}=1$, $p=0.859$ ). It is not possible to analyze the separate effects of kelp and mussels in this data set. However, the 2 EBP lobsters found on unvegetated bedrock were in mussel clumps (Table 1a) which have cobble-like interstices.

On sediment substrata EBP densities were not enhanced by vegetation (Table 1a). For example, the eelgrass habitat of $\mathrm{PH}$ was virtually uninhabited by EBP lobsters (1 EBP in 23 quadrats) as was the featureless mud habitat ( 0 in 20 quadrats), while the immediately adjacent unvegetated cobble bottom supported one of the densest populations censused (Table 1a).

Other factors besides substratum appear to have had little effect on the observed pattern of abundance. Early benthic phase population densities within the cobble substratum did not vary consistently by depth or year among sites (Table $1 b$ ). Densities at the $5 \mathrm{~m}$ depth were significantly greater than at $10 \mathrm{~m}$ (by 2 -factor ANOVA; Table 1 b) only at DI, and significant temporal changes occurred only at OP and PP. It is unclear what, if any, ecological importance can be attributed to the statistically significant interaction between depth and year at OP. There were no trends from estuary to outer coast since we found high densities at opposite ends of 
the transect. Nor were consistent patterns found with depth. Clearly, within the shallow depth range examined, substratum appears to be the overriding factor associated with differences in EBP densities.

\section{Habitat and abundance of EBP lobsters}

\section{Cobble substratum: its abundance and size composition}

The relative abundance of cobble substratum ranged from 3 to $16 \%$ along the shorelines of the Pemaquid area (Table 2). Urchin-grazed bedrock, colonized by encrusting coralline algae but devoid of fleshy macroalgae, characterized the shores of the mainland and outer islands while mud was most abundant in the estuary (PH).

Most cobble patches are heterogeneous mixtures of variously sized rocks and mussels (Fig. 3). If we assume that shelter availability is linearly related to the number of rocks and mussels greater than or equal to a minimum size which create habitable spaces, then substratum size-frequency distributions should indicate the abundance of potential shelters. Since larger rocks occupy more space, the density of shelters is inversely related to rock size. This is evident in the distribution of cobbles generated from photoquadrats (Fig. 3b). Photoquadrats were not possible at RI because of poor visibility. From the smallest ( 2 Phi) to the largest ( $\geq 7$ Phi) rock size there was a decline in rock (and presumably shelter) density by a factor of 10 . Small differences in the percent cover (Fig. 3a) of small rock size categories accounted for the large variance in numerical abundance. Exceptions to the overall decline resulted from (1) mussels augmenting the 4,5, and 6 Phi size classes especially at $\mathrm{PH}$, and (2) pooling all rocks $\geq 7$ Phi into one category. Rocks rarely exceeded $400 \mathrm{~mm}$ (8.65 Phi) in diameter at our study sites.

The observed number of rocks in each category is contrasted with the maximum possible number of rocks of each size category (Fig. 3b). Since larger rocks cover such a large proportion of the bottom (Fig. 3a), they occlude the view of smaller rocks below them. Thus, smaller rocks and shelters are probably under-represented.

\section{Cobble cover and EBP abundance}

Cobbles provide numerous interstitial spaces suitable as shelter for EBP lobsters. Operationally we define 'shelter-providing substratum' as the rock size that, in aggregate, provides habitable spaces that can accommodate the lobster body. The geometry and body size scaling of shelter-providing substratum is
Table 2. Substratum availability as determined by shoreline surveys in the Pemaquid study area delineated in Fig. 1

\begin{tabular}{|lcccl|}
\hline & $\begin{array}{c}\text { Shoreline } \\
(\mathrm{km})\end{array}$ & \multicolumn{3}{c|}{ Proportion } \\
& Cobble & Sediment & Ledge \\
\hline Estuary & 13.8 & 0.034 & 0.965 & 0 \\
Inner coast & 26.4 & 0.165 & 0.030 & 0.805 \\
Outer coast & 20.0 & 0.081 & 0.016 & 0.903 \\
Total & 60.2 & 0.107 & 0.238 & 0.652 \\
\hline
\end{tabular}

fully analyzed in Wahle (1990). The scatterplot in Fig. 4 suggests a positive relationship between EBP abundance and the percent cover of rocks $\geq 5$ Phi $(32 \mathrm{~mm}$ ) maximum diameter, a rock size providing adequate shelter for newly settled lobsters. These data illustrate the absence of EBP lobsters in sediment habitats and an increasing range of EBP population density with

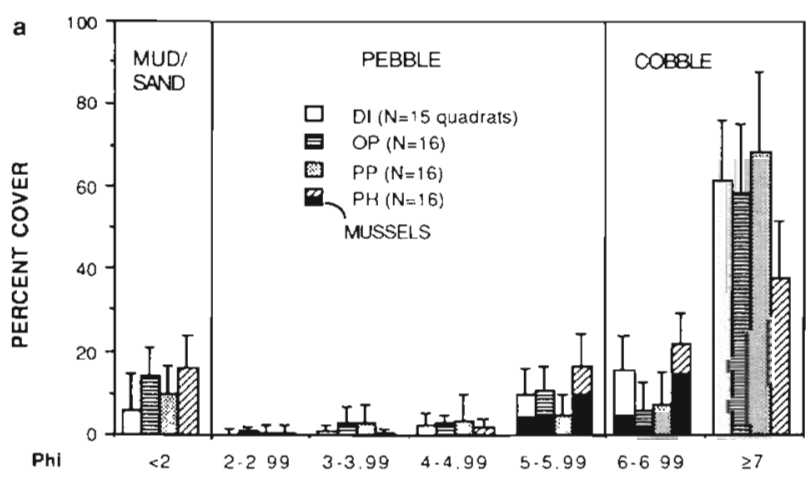

b

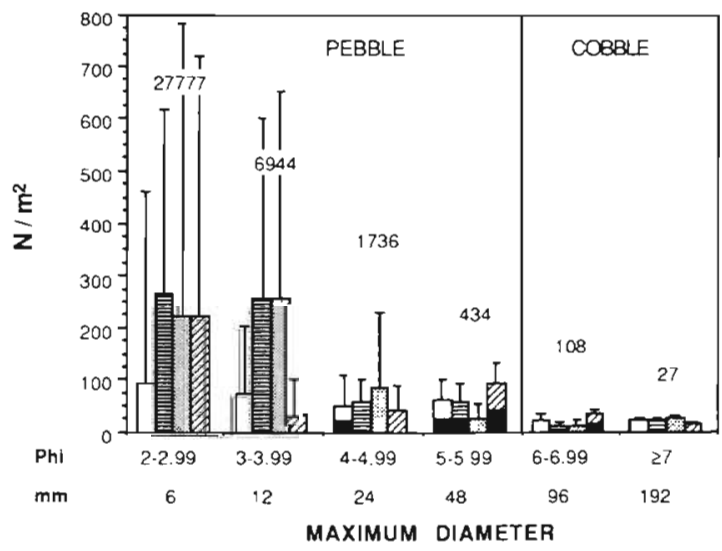

Fig. 3. Substratum composition of cobble habitats 4 sites at $5 \mathrm{~m}$ depth in the Pemaquid region. Each bar is mean +1 SD. Standard terms for substratum catagories after Wentworth (1922, in Shepherd 1964). (a) Percent cover of all substratum size classes including those used to calculate the size-frequency distribution, (b) of rocks and mussels $\geq 2$ Phi. In (b) the midpoints of Phi size classes are shown in mm. Numbers over bars are the maximum number $\mathrm{m}^{-2}$ possible for the midpoint of each size class. Phi units are positive $\log _{2}$ of diameter (not negative as is conventional). Mussels showns as black portion of bar 


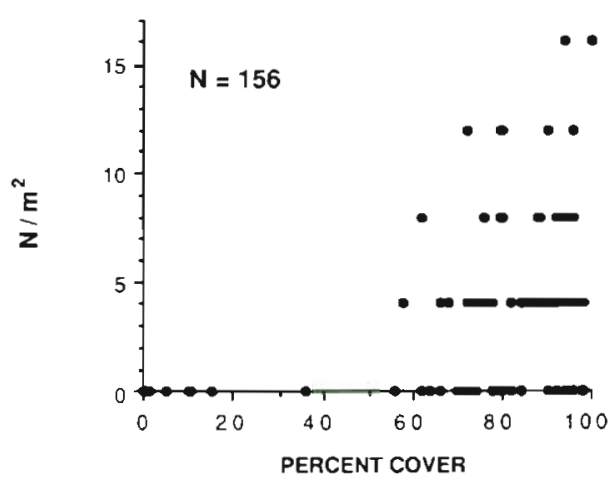

Fig. 4. Homarus americanus. Lobster ( $\leq 40 \mathrm{~mm}$ CL) population density versus substratum composition (percent cover of rocks $\geq 5$ Phi). All points are not visible because of overlap (e.g. 93 points fall below the $20 \%$ cover level)

greater cobble cover. They represent quadrats sampled at $5 \mathrm{~m}$ depth from DI, OP, PP, and PH in 1988 (63 quadrats) and unvegetated sediment from DI, RI, OP, and $\mathrm{PH}$ in 1987 (93 quadrats). Data are sparse for intermediate values of percent cover because the stratified sampling of sediment and cobble substrata left out transitional habitats.

Although mussels provide cover for EBP lobsters on otherwise featureless ledges (described above), they apparently do not enhance or detract from the quality of cobble habitats. Thus, there was no relationship between mussel cover $(\mathrm{X})$ and EBP abundance ( $\mathrm{Y}=$ $3.09+0.05 X, R^{2}=0.02, N=63, p=0.25$ ) in cobble habitats. Mussel cover in cobble at $5 \mathrm{~m}$ where photoquadrats were taken ranged from 0 to $44 \%$, with site averages of $11 \%$ at DI, $7 \%$ at OP, $1 \%$ at PP, and $22 \%$ at $\mathrm{PH}$. Clearly, in this case, any relationship would be confounded by the presence of cobbles and the value of mussel beds as a recruitment habitat remains unresolved.

\section{Regional demography}

EBP lobsters were found in 3 of the 4 study areas within the Gulf of Maine (Table 3). Population densities in the Rye and Nahant areas were generally consistent with or slightly lower than the Pemaquid area. In contrast, no EBP lobsters were found at any of the sites in the Swans Island area although cobble habitats were common. This apparently vacant habitat raises questions of larval supply which are discussed below.

\section{DISCUSSION}

\section{Habitat restrictions of the EBP}

Benthic censuses suggest that the early benthic phase is the most habitat-restricted segment of lobster life. The strong association of EBP lobsters with rocky habitats is consistent with the field surveys of Bernstein \& Campbell (1983), and Hudon (1987). The strength of

Table 3. Homarus americanus. Lobster densities $(\leq 40 \mathrm{~mm} \mathrm{CL})^{\mathrm{a}}$ from the regional survey beyond the Pemaquid study area

\begin{tabular}{lcccl} 
& $N^{-2}$ & SD & $\begin{array}{c}\text { No. } \\
\text { quadrats }\end{array}$ & Substratum description \\
\hline Nahant & & & & \\
Canoe Beach I & 0.8 & 0.2 & 10 & Cobble \\
Canoe Beach II & 2.8 & 3.3 & 26 & Cobble - boulder \\
Saunders Ledge & 0.1 & 0.3 & 10 & Boulders-vegetated \\
Rye & & & & Unvegetated cobble - vegetated boulders \\
Ragged Neck Pt. & 2.0 & 2.8 & 16 & Cobble \\
Swans Island Region & & & & Bedrock \\
Marshal Is. I & 0 & 0 & 10 & Sand \\
Marshal Is. It & 0 & 0 & 10 & Cobble - boulder \\
Marshal Is. III & 0 & 0 & 14 & Cobble - boulder \\
Harbor Is. (near Long Is.) & 0 & 0 & 13 & Cobble - boulder \\
Crow Is. & 0 & 0 & 12 & Cobble - boulder \\
Black Is. & 0 & 0 & 9 & Cobble - boulder \\
Long Is. & 0 & 0 & 10 & Cobble \\
Swans Is., East & 0 & 0 & 9 & Cobble - boulder \\
Swans Is., North & 0 & 0 & 10 & \\
Swans Is., West & 0 & 0 & 10 & \\
Harbor Is. (near Swans Is.) & 0 & 0 & 10 & \\
anly 1 individual larger than 40 mm CL was collected & & \\
\hline
\end{tabular}


the association suggests that shelter-providing habitat is a necessary prerequisite for recruitment to the benthos as suggested by Caddy (1986) and Fogarty \& Idoine (1986).

Support for the name 'Early benthic phase'

Previous workers have recognized that small juvenile American lobsters are behaviorally and ecologically distinct from larger ones. Small juveniles tend to be cryptic and escape-prone when threatened, whereas larger juveniles and adults tend to be aggressive and wide ranging. Lang et al. (1977) deciphered the neurological basis for this difference in the development of the lobster central nervous system a decade before Hudon (1987) found demographic evidence of it in the field. Hudon called lobsters $\leq 25 \mathrm{~mm}$ carapace length (CL) 'postlarval'; the larger juveniles (25 to $73 \mathrm{~mm} \mathrm{CL}$ ) 'juvenile'; and reproductive lobsters (>73 mm CL) 'adult'. Based on long-term laboratory studies, Barshaw \& Bryant-Rich (1988) named 2 juvenile 'substages': (1) the 'early juvenile stage' from settlement to the time the right and left claws begin to differentiate; and (2) the 'late juvenile stage' after the claws differentiate until sexual maturity.

We argue that these terms are inappropriate. First, the term 'stage' is not accurate because, unlike developmental stages that are linked to specific molts, the behavioral transition from one behavioral state to another is gradual and we therefore suggest the term 'phase'. For the same reason it is inappropriate to specify a precise body size at which the transition occurs where a range is more accurate. Second, the term 'postlarval' is gaining favor among lobster specialists as a term to be reserved for the post-metamorphic settlement stage (IV) of clawed lobsters and not later stages (see Lobster News Letter vol. 2, no. 1, p. 4, 1989). Third, the reason for using claw differentiation as the criterion for distinguishing an 'early' and 'late juvenile stage' (Barshaw \& Bryant-Rich 1988) is not clear to us because Costello \& Lang (1979) demonstrated differentiation beginning at stage $\mathrm{V}$ and VI, almost immediately after settlement.

\section{Mechanisms reinforcing the association}

Field experiments to determine the processes and mechanisms behind the association of EBP lobsters with sheltering substrata will be important to understanding whether a demographic bottleneck to recruitment exists. EBP lobsters have only rarely been observed to occupy burrows in featureless sediment in nature (McKay 1926), although they are quite adept burrowers (Berrill \& Stewart 1973, Botero \& Atema 1982). This raises the question of the consequences of occupying that substratum to an EBP lobster in nature. It is likely that shelter-seeking is an adaptive response to predation (e.g. Roach 1983, Lavalli \& Barshaw 1986, Richards \& Cobb 1986, Barshaw \& Lavalli 1988), but there may be other advantages of occupying structurally complex habitats such as escaping strong currents (Howard \& Nunny 1983, Johns \& Mann 1987) or for the associated foods (see Scarratt 1968, Hudon \& Lamarche 1989, Wahle 1990)

The close association with sheltering habitats appears to relax gradually as lobster grow out of the early benthic phase (Fig. 2; Hudon 1987). The present study (Table 1a, Fig. 2) and Hudon's (1987) work have added demographic support to the morphological, and behavioral (Lang et al. 1977, Lawton 1987) bases for distinguishing EBP lobsters from larger individuals that range more widely with greater body size (Fig. 2; Hudon 1987). This distributional shift is analogous to predator-mediated habitat shifts observed in freshwater fishes (Werner et al. 1983, Werner \& Gilliam 1984) and crayfish (Stein \& Magnuson 1976) that pass through a similar range in body size.

\section{Habitat area and benthic recruitment}

If we assume that larvae are only passively dispersed, it could be argued that benthic recruitment may be proportional to the availability of suitable recruitment habitat. Cobble habitats are characteristically patchy and comprise a small fraction of available bottom at our study area (Table 2), and along much of the Maine coast (Kelley 1987). This may generally be the case over the geographic range of the American lobster (e.g. see descriptions of lobster habitat in Canada; Ennis 1983, Hudon et al. 1986, Hudon 1987), especially in the predominantly sand habitats in southern New England and the mid-Atlantic states. Thus, it is possible that substratum availability may fundamentally limit recruitment, regardless of whether or not these habitats are at carrying capacity. Active swimming and delayed settlement (e.g. Cobb 1968, Botero \& Atema 1982, Barshaw 1988) can improve the chances of finding suitable habitats, but the distances over which these mechanisms can effectively concentrate settlement are not known.

The proportion of cobble habitat is not likely to change year to year, but biotic substrata like kelp and mussels may vary to the extent their coverage is influenced by consumers (Kitching et al. 1959, Mann \& Breen 1972, Pringle et al. 1980, Miller 1985). Some of these biotic habitats have great potential as lobster recruitment sites, but regional estimates of their areal 
extent remain to be done. Other workers have found EBP lobsters in, or have investigated the potential of, subtidal habitats such as macroalgae (Laminaria spp.: Miller 1985; Chondrus crispus: Johns \& Mann 1987), eelgrass (Zostera marina: Hudon 1987, Barshaw 1988), and Spartina 'peat reefs' (Able et al. 1988). The common denominator among these examples is the availability of small shelter spaces

We found eelgrass beds to support low densities of lobsters of all sizes (Table 1a) as have Hudon (1987) and Heck et al. (1989). The rarity of EBP lobsters from our eelgrass site (PH) is striking considering that over 90000 hatchery-reared lobster postlarvae were released there over a 3 yr period (1985-1987, Samual Chapman, University of Maine, pers comm.). We did not investigate subtidal Spartina 'peat reefs' but such habitats examined by Able et al. (1988) had average EBP densities of $2.1 \mathrm{~m}^{-2}$ using a suction sampler. This substratum may be of value where it is not subject to aerial exposure, low salinities, or freezing. In Gulf of Maine salt marshes, such conditions are extremely rare. Mussel beds remain unexamined as a recruitment habitat for lobsters, but structurally are similar to cobble habitat, and barring limiting salinities or temperatures, are potentially important recruitment sites. The value of macroalgae as a recruitment habitat was hypothesized by Johns \& Mann (1987) and was supported in a limited way in this study (Table 1a).

\section{Within the recruitment habitat: are cobble beds saturated?}

Fogarty \& Idoine (1986) speculated that larval production in Northumberland Strait, Canada exceeded the carrying capacity of benthic recruitment habitats. However, to date there is no empirical evidence that lobster recruitment habitats are at carrying capacity. Our substratum analysis suggests that within cobble habitats there are far more shelters available than there are EBP lobsters. This suggests that these habitats are either undersaturated or that lobsters have spatial requirements that we do not yet understand (i.e. a foraging area; Lawton 1987). In general, our data suggest a positive relationship between EBP abundance and the percent cover of shelter-providing substratum within our quadrats (Fig. 4). We observed maximum densities of $16 \mathrm{~m}^{-2}$ in quadrats having $100 \%$ cobble cover, but relatively few of the quadrats with good cobble cover had densities near this level, suggesting other factors may be limiting densities. Nevertheless, our maximum field densities approach the laboratory findings of Van Olst et al. (1976) whose mass rearing systems sustained average densities ranging from 6 to 30 per $\mathrm{m}^{2}$ of lobsters 14 to $18 \mathrm{~mm} \mathrm{CL}$ depending on substratum. Clearly, understanding the sheltering qualities of a habitat is only one of several factors determining the carrying capacity for lobsters. Not least of these factors are size-specific aggression and trophic requirements of lobsters outside shelters (e.g Scarratt 1968, Lawton 1987). Thus, while EBP lobsters appear to be limited to shelter-providing habitats, the processes determining their densities within these habitats remain uncertain

\section{Regional discontinuities in recruitment}

The sites censused at Swans Island stand apart from those to the southwest by the absence of EBP lobsters (Table 3). If EBP lobsters are restricted to cobble and other shelter-providing habitats, recruitment could not have occurred at these sites for at least 2 to $3 \mathrm{yr}$. Massive post-settlement mortality seems unlikely to explain their absence because predators and potential competitors (crabs; Richards \& Cobb 1986) were not dramatically more numerous than in other locations censused (Wahle unpubl.). Similarly, Huntsman (1923) observed that the Bay of Fundy stood apart from other regions of the Canadian Maritimes by the low numbers of juvenile lobsters in commercial catches. He also noted that the region distinguished itself by having low larval densities, and low summer temperatures. He suggested that cool temperatures could inhibit lobster settlement, and that the fishery there was more dependent on lobsters immigrating along the bottom from other locations

Swans Island and the rest of the northeastern Maine coast are more heavily influenced by the cold tidal plume from the Bay of Fundy than locations to the southwest (Colton \& Stoddard 1972. Townsend et al. 1987). Since Huntsman's time, plankton surveys have suggested that larval lobsters densities in the northeast Gulf of Maine and Bay of Fundy (Leim 1936, Greenstein et al. 1976, Groom 1978, Locke \& Corey 1988) are lower than those to the southwest (Fair 1980, Fogarty 1983) and other parts of the Canadian Maritimes (Stasko 1980). Moreover, numerous studies have shown that lobster larval development is dramatically inhibited by cold temperatures (Huntsman 1923, Templeman 1936, Wilder 1953, MacKenzie 1988). While it is tempting to speculate that lobster recruitment is thermally mediated on the regional scale, more details on larval behavior, thermography, and benthic distribution of EBP lobsters are required.

In summary, the American lobster appears to be restricted to shelter-providing habitats in its early benthic life, but this restriction apparently relaxes as it grows. We define this restricted segment of lobster life as the early benthic phase; and because its recruitment habitats, such as cobble and other shelter-providing 
habitats, comprise a relatively small proportion of the available substrata, they may fundamentally limit benthic recruitment. Although shelter availability appears to be a major determinant of the abundance of EBP lobsters within these habitats, the relative importance of pre- and post-settlement processes in influencing population densities awaits further study.

Acknowledgements. This research was supported by Maine Sea Grant \# NA 86 AA-D-SG 047 and NA 89 AA-D-SG 020. Generous contributions toward specific aspects of this study were made by Sigma Xi, the Lerner-Grey Foundation, the Migratory Fish Research Institute (University of Maine), the Lobster Institute (University of Maine), and the Association for Graduate Students (University of Maine). I owe my gratitude to the summer interns of 1987 and 1988 with special thanks to Paul Humphries. Dick Cooper helped with his knowledge of sites in the Pemaquid study area; and Ken Heck and Ken Able gave helpful advice on the use of suction samplers. I thank the mechanical staff of the Darling Marine Center for keeping my field operation afloat. The manuscript was improved by the thoughtful comments of $J$. Stanley Cobb, John Dearborn, Sally Hacker, Kenneth Heck, Christiane Hudon, Irv Kornfield, Les Watling, and 2 anonymous reviewers.

\section{LITERATURE CITED}

Able, K. W., Heck, K. L., Fahay, M. P., Roman, C. T (1988). Use of salt-marsh peat reefs by small juvenile lobsters on Cape Cod, Massachusetts. Estuaries 11. 83-86

Aiken, D. E., Waddy, S. L. (1980). Reproductive biology. In: Cobb, J. S., Phillips, B. F. (eds.) The biology and management of lobsters, Vol. 2. Academic Press, New York, p. 215-276

Barshaw, D. E. (1988). Substrate-related behavior and predator-prey interactions of the early juvenile lobster, Homarus americanus. Ph. D. dissertation, Boston University

Barshaw, D. E., Bryant-Rich, D. R. (1988). A long-term study on the behavior and survival of early juvenile American lobster, Homarus americanus, in three naturalistic substrates: eelgrass, mud, and rocks. Fish. Bull. U.S. 86 : 789-796

Barshaw, D. E., Lavalli, K. 1. (1988). Predation upon postlarval lobsters, Homarus americanus, by cunners, Tautogolabrus adspersus, and mud crabs, Neopanope sayi, on three different substrates: eelgrass, mud, and rocks. Mar. Ecol. Prog. Ser. 48: 119-123

Bernstein, B., Campbell, A. (1983). Contribution to the development of methodology for sampling and tagging small juvenile lobsters. Can. MS Tech. Rept Fish. Aquat. Sci. $1741.36 \mathrm{pp}$

Berrill, M., Stewart, R. (1973). Tunnel digging in mud by newly settled American lobsters, Homarus americanus. J. Fish. Res. Bd Can. 30: 285-287

Bertness, M. (1981). Competitive dynamics of a tropical hermit crab assemblage. Ecology 62: 751-761

Botero, L., Atema, J. (1982). Behavior and substrate selection during larval settling in the lobster Homarus americanus. J. Crustacean Biol. 2: 59-69

Caddy, J. F. (1986). Modelling stock-recruitment processes in Crustacea: some practical and theoretical perspectives. Can. J. Fish. Aquat. Sci. 43: 2330-2344

Campbell, A. (1986). Migratory movements of ovigerous lob- sters, Homarus americanus, tagged off Grand Manan, eastern Canada. Can. J. Fish. Aquat. Sci. 43: 2197-2205

Campbell, A., Pezzack, D. S. (1986). Relative egg production and abundance of berried lobsters, Homarus americanus, in the Bay of Fundy off southwestern Nova Scotia. Can. J. Fish. Aquat. Sci. 43: 2190-2196

Campbell, A., Stasko, A. B. (1985). Movements of tagged American lobster, Homarus americanus, of southwestern Nova Scotia. Can. J. Fish. Aquat. Sci. 42: 229-238

Campbell, A., Stasko, A. B. (1986). Movements of lobsters (Homarus americanus) tagged in the Bay of Fundy, Canada. Mar. Biol. 92: 393-404

Cobb, J. S. (1968). Delay of moult by the larvae of Homarus americanus. J. Fish. Res. Bd Can. 25: 2251-2253

Cobb, J. S. (1986). Summary of session 6. International workshop on lobster recruitment. Can. J. Fish. Aquat. Sci. 43: 2389-2390

Cobb, J. S., Gulbranson, T., Phillips, B. F., Wang, D., Syslo, M. (1983). Behavior and distribution of larval and early juvenile Homarus americanus. Can. J. Fish. Aquat. Sci. 40: 2184-2188

Cobb, J. S., Wang, D. (1985). Fisheries biology of lobsters and crayfish. In: Provenzano, A. J. (ed.) The biology of Crustacea, Vol. 10. Academic Press, New York, p. 167-247

Cobb, J. S., Wang, D., Campbell, D. B. (1989). Timing and settlement by postlarval lobsters (Homarus americanus): field and laboratory evidence. J. Crustacean Biol. 9: 60-66

Colton, J. B. Stoddard, R. R. (1972). Average monthly seawater temperatures: Nova Scotia to Long Island, 1940-1959. Serial atlas of the marine environment. Folio 21 A.m. Geogr Soc. New York

Conan, G. Y (1986). Summary of session 5. Can. J. Fish. Aquat. Sci. 43: 2384-2388

Cooper, R. A., Clifford, R. A., Newell, C. D. (1975). Seasonal abundance of the American lobster, Homarus americanus, in the Boothbay region of Maine. Trans. Am. Fish. Soc. 104: 669-674

Cooper, R. A., Uzmann, J. R. (1971). Migrations and growth of deep sea lobsters, Homarus americanus. Science 171: 288-290

Costello, W. J., Lang, F. (1979). Development of the dimorphic claw muscles of the lobster, Homarus americanus. IV. Changes in functional morphology during growth. Biol. Bull. mar biol. Lab., Woods Hole 156: 179-195

Ennis, G. P. (1975). Observations on hatching and larval releases in the lobster Homarus americanus. J. Fish. Res. Bd Can. 32: 2210-2213

Ennis, G. P. (1983). The effect of wind direction on the abundance and distribution of decapod crustacean larvae in a Newfoundland nearshore area. Can. Tech. Rep. Fish. Aquat Sci. 1138: 1-19

Ennis, G. P. (1984). Small scale seasonal movements of the American lobster, Homarus americanus. Trans. Am. Fish. Soc. $113: 336-338$

Fair, J. J. (1980). U.S. surveys of lobster larvae. Can. Tech. Rep. Fish. Aquat. Sci. 932: 153-155

Fogarty, M. J. (1983). Distribution and relative abundance of American lobster, Homarus americanus, larvae: a review. In: M. J. Fogarty (ed.) Distribution and relative abundance of American lobster, Homarus americanus, larvae: New England investigations during 1974-79. NOAA Tech. Rep. NMFS SSRF-775, p. 3-7

Fogarty, M. J., Idoine, J. S. (1986). Recruitment dynamics in an American lobster (Homarus americanus) population. Can. J. Fish. Aquat. Sci. 43: 2368-2376

Greenstein, D. M., Alexander, L. C., Richter, D. E. (1976). Abundance and distribution of lobster larvae (Homarus 
americanus) for selected locations in Penobscot Bay, Maine. In: M. J. Fogarty (ed.) Distribution and relative abundance of American lobster, Homarus americanus, larvae: New England investigations during 1974-79. NOAA Tech. Rep. NMFS SSRF-775, p. 59-61

Groom, W (1978). Interim investigation of lobster stock, size and migration system of lobster populations in the Grand Manan region. New Brunswick Dept. Fish. Rep., 1-69

Harding, G. C., Drinkwater, K. F., Vass, W. P. (1982). Factors influencing the size of American lobster stocks along the Atlantic coast of Nova Scotia, Gulf of St. Lawrence, and Gulf of Maine: a new synthesis. Can. J. Fish. Aquat. Sci. 40: $168-184$

Harding, G. C., Trites, R. W (1988). Dispersal of Homarus americanus larvae in the Gulf of Maine from Browns Bank. Can. J. Fish. Aquat. Sci. 45: 416-425

Heck, K. L., Able, K. W., Fahay, M. P., Roman, C. T (1989). Fishes and decapod crustaceans of Cape Cod eelgrass meadows: species composition, seasonal abundance patterns and comparison with unvegetated substrates. Estuaries: 59-65

Howard, A. E. (1980). Substrate controls on the size composition of lobster (Homarus gammarus) populations. J. Cons. int. Explor. Mer 39: 130-133

Howard, R. K. (1988). Fish predators of the western rock lobster (Panulirus cygnus George) in a nearshore nursery habitat. Aust. J. mar Freshwat. Res. 39: 307-316

Howard, A. E., Bennett, D. B. (1979). The substrate preference and burrowing behavior of juvenile lobsters (Homarus gammarus). J. nat. Hist. 13: 433-438

Howard, A. E., Nunny, R. S. (1983). Effects of near-bed current speeds on the distribution and behavior of the lobster Homarus gammarus. J. exp. mar. Biol. Ecol. 71: 27-42

Hudon, C. (1987). Ecology and growth of post-larval and juvenile lobster, Homarus americanus, off Isle de la Madeleine (Quebec). Can. J. Fish. Aquat. Sci. 44: $1855-1869$

Hudon, C., Fradette, P., Legendre, P. (1986). La repartition horizontale et verticale des larves de homard (Homarus americanus) autour des Iles de la Madeleine, golfe du Saint-Laurent. Can. J. Fish. Aquat. Sci. 43: 2164-2176

Hudon, C., Lamarche, G. (1989). Niche segregation between American lobster, Homarus americanus, and rock crab, Cancer irroratus. Mar. Ecol. Prog. Ser. 52: 155-168.

Huntsman, A. G. (1923). Natural lobster breeding. Bull. biol. Bd Can. 5: 1-11

Johns, P. M., Mann, K. H. (1987). An experimental investigation of juvenile lobster habitat preference and mortality among habitats of varying structural complexity. J. exp. mar Biol. Ecol. 109: 275-285

Kelley, J. (1987). Sedimentary environments along Maine's estuarine coastline. In: FitzGerald, D. M., Rosen, P. S. (eds.). A treatise on glaciated coasts. Academic Press, New York, p. 151-176

Kitching, J. A., Sloane, J. F., Ebling, F. J. (1959). The ecology of Lough Ine VII. Mussels and their predators. J. Anim. Ecol. 28: 331-341

Krouse, J. S. (1980). Summary of lobster, Homarus americanus, tagging studies in American waters (1898-1978). Can. Tech. Rep. Fish. Aquat. Sci. 932: 136-140

Krouse, J. S. (1981). Movement, growth, and mortality of American lobsters, Homarus americanus, tagged along the coast of Maine. NOAA Tech. Rep. NMFS-SSRF 747 p. 1-12

Lang, F., Govind, C. K., Costello, W. J., Greene, S.I. (1977). Developmental neuroethology: changes in escape and defensive behavior during growth of the lobster. Science 197: $682-684$
Lavalli, K. L., Barshaw, D. E. (1986). Burrows protect postlarval lobster, Homarus americanus, from predation by the nonburrowing cunner, Tautogoglabrus adspersus, but not from the burrowing mud crab, Neopanope texani. Mar Ecol. Prog. Ser. 32: 13-16

Lawton. P. (1987). Diel activity and foraging behavior of juvenile American lobsters, Homarus americanus. Can. J. Fish. Aquat. Sci. 44: 1195-1205

Leim, A. H. (1937). Herring Gulls and lobster Iarvae. Ann. Rep. Biol. Bd Can. 1936: 9-18

Locke, A., Corey, S. (1988). Taxonomic composition of Euphausiacea and Decapoda (Crustacea) in the neuston of the Bay of Fundy, Canada. J. Plankton Res. 10: 185-198

MacKenzie, B. R. (1988). Assessment of temperature effects on interrelationships between stage durations, mortality, and growth in laboratory-reared Homarus americanus Milne Edwards. J. exp. mar. Biol. Ecol. 116: 87-98

Mann, K. H. Breen, P. A. (1972). The relation between lobster abundance, sea urchins, and kelp beds. J. Fish. Res. Bd Can. 29: 603-609

Marx, J., Herrnkind, W (1985). Factors regulating microhabitat use by young juvenile spiny lobsters, Panulirus argus: food and shelter. J. Crustacean Biol. 5: 650-657

McKay, D. A. (1926). Post larval lobsters. Science 64:530

Miller, R. J. (1985). Seaweeds, sea urchins, and lobsters: a reappraisal Can. J. Fish. Aquat. Sci. 42: 2061-2072

Moran, D. P., Reaka, M. L. (1988). Bioerosion and availability of shelter for benthic reef organisms. Mar. Ecol. Prog. Ser 44: $249-263$

Munro, J., Therriault, J. C. (1983). Migration sajssonieres du homard (Homarus americanus) entre la cote et les lagunes des lles-de-la-Madeleine. Can. J. Fish. Aquat. Sci. 40: 905-918

Pezzack, D. S., Duggan, D. R. (1986). Evidence of migration and homing of lobsters (Homarus americanus) on the Scotian Shelf. Can. J. Fish. Aquat. Sci. 43: 2206-2211

Phillips, B. F., Sastry, A. N. (1980). Larval ecology. In: Cobb, J. S., Phillips, B. F. (eds.) The biology and management of lobsters, Vol. 2. Academic Press, New York, p. 11-57

Pottle, R. A., Elner, R. W. (1982). Substrate preference behavior of juvenile American lobsters, Homarus americanus, in gravel and silt-clay sediments. Can. J. Fish. Aquat. Sci. 39: 928-932

Pringle, J. D., Sharp, G. J., Caddy, J. F. (1980). Interactions in kelp bed ecosystems in the northwest Atlantic: review of a workshop. Can. Spec. Publ. Fish. Aquat. Sci. 59: $108-115$

Quinn, J. P., Janssen, J. (1989). Crayfish competition in southwestern Lake Michigan: a predator mediated bottleneck. J. Freshwater Ecol.: 75-85

Richards, R. A., Cobb, J. S. (1986). Competition for shelter between lobsters (Homarus americanus) and Jonah crabs (Cancer borealis): effects of relative size. Can. J. Fish. Aquat. Sci. 43: 2250-2255

Roach, G. (1983). Survivorship, growth, and behavior of juvenile lobsters, Homarus americanus Milne-Edwards, in controlled environments in nature. MS Tech. Rept. 83-02 Nova Scotia Dept. Fish. 60 pp.

Scarratt, D. J. (1968). An artificial reef for lobsters (Homarus americanus). J. Fish. Res. Bd. Can. 25. 2683-2690

Scarratt, D. J. (1973). Abundance, survival, and vertical and diurnal distribution of lobster larvae in Northumberland Strait, 1962-1963, and their relationship with commercial stocks. J. Fish. Res. Bd. Can. 30: 1819-1824

Shepherd, F. P. (1964). Submarine geology. Harper and Row, New York

Spanier, E., Zimmer-Faust, R. K. (1988). Some physical prop- 
erties of shelter that influence den preference. J. exp. mar. Biol. Ecol. 121. 137-149

Stasko, A. B. (1980). Lobster larval surveys in Canada. Can. Tech. Rep. Fish. Aquat. Sci. 932: 157-165

Steger, R. (1987). Effects of refuges and recruitment on gonodactylid stomatopods, a guild of mobile prey. Ecology 68: $1520-1533$

Stein, R., Magnuson, J. J. (1976). Behavioral response of crayfish to a fish predator. Ecology $57 \cdot 751-761$

Stewart, L. L. (1972). The seasonal movements, population dynamics, and ecology of the lobster, Homarus americanus, off Ram island, Connecticut. Ph.D. dissertation, University of Connecticut

Templeman, W. (1936). The influence of temperature, salinity, light, and food conditions on the survival and growth of the lobster, Homarus americanus. J. Biol. Bd Can. 2: 485-497

Townsend, D. W., Christiansen, J. P., Stevenson, D. K., Graham, J. J., Chenowith, S. B. (1987). The importance of a plume of tidally mixed water to the biological oceanography of the Gulf of Maine. J. mar. Res. 45: 699-728

Underwood, A. J. (1981). Techniques of analysis of variance in experimental marine biology and ecology. Oceanogr. mar. Biol. A. Rev. 19: 513-605

Uzmann, J. R., Cooper, R. A., Pecci, K. J. (1977). Migration and dispersion of tagged American lobsters, Homarus americanus, on the southern New England continental shelf. NOAA Tech. Rep. NMFS-SSRF 705, p. 1-91

This article was submitted to the editor
Van Olst, J. C., Carlberg, J. M., Ford, R. F. (1976). Effect of substrate type and other factors on the growth, survival, and cannibalism of juvenile Homarus americanus in mass rearing systems. Proc. Wld Maricult. Soc. 6: 261-274

Vance, R. R. (1972). The role of shell adequacy in behavioral interactions unvolving hermit crabs. Ecology 53: $1076-1083$

Wahle, R. A. (1988). Recruitment and body size-dependent habitat selection and predator impact on early benthic phase American lobsters (Homarus americanus Milne Edwards). Am. Zool. 28: 14 (Abstract)

Wahle, R. A. (1990). Recruitment, habitat selection, and the impact of predators on the early benthic phase of the American lobster (Homarus americanus Milne Edwards). Ph. D. dissertation, University of Maine

Werner, E. E., Gilliam, J. F. (1984). The ontogenetic niche and species interactions in size-structured populations. Ann. Rev. Ecol. Syst. 15: 393-425

Werner, E. E., Gilliam, J. F., Hall, D. J., Mittelbach, G. G. (1983). An experimental test of the effects of predations risk on habitat use in fish. Ecology $64: 1540-1548$

Wilder, D. G. (1953). The growth rate of the American lobster (Homarus americanus). J. Fish. Res. Bd Can. 10: 371-412

Yoshimura, T., Yamakawa, H. (1988). Microhabitat and the behavior of settled pueruli and juveniles of the Japanese spiny lobster Panulirus japonicus at Kominato, Japan. J. Crustacean Biol. 8: 524-531

Manuscript first received: September 19, 1989

Revised version accepted: October 22, 1990 